Acta Universitatis Wratislaviensis No 3998

Anglica Wratislaviensia LVIII, Wrocław 2020

https://doi.org/10.19195/0301-7966.58.9

\author{
Danuta Gabryś-Barker \\ ORCID: 0000-0003-0626-0703 \\ University of Silesia \\ danuta.gabrys-barker@us.edu.pl
}

\title{
The Practice of Classroom Code-Switching, Translanguaging or Simply Alternating Languages in FL Teacher Talk
}

\begin{abstract}
Alternating between languages in an FL classroom is first of all observed in teacher talk which is an important dimension of FL teachers' discourse. (Tsui 2008). The empirical study presented here focuses on the language choices made between the L1 and FL(s) by both in-service teachers (group 1) and pre-service trainees (group 2) during English lessons - but it is not meant to be an in-depth debate on L1/FL use in a language classroom. It is a small-scale diagnostic study of a FL classroom and TT behaviour of the subjects. The text starts with a brief presentation of the concepts of code-switching and translanguaging, as applied in educational contexts and here operationalized for the purposes of a pilot study on language choices in teacher talk. The observations of EFL lessons focus on the purpose(s) language alterations are made by the teachers and seek to reflect on the extent to which these purposes refer to clearly-defined instructional functions - cognitive but also affective ones. These language choices made also constitute an important pedagogical dimension beyond language instruction itself. The results of the study show that both experienced and trainee teachers switch languages consciously during the lesson at similar stages and for similar purposes, however some differences are also observed and discussed in the text. The major focus of discussion is on the pre-service teachers, as the study is part of awareness raising, and thus reflectivity enhancement of trainees participating in their teacher training at the undergraduate level (BA) but who are already active teachers in the period of their school placement.
\end{abstract}

Keywords: code-switching, translanguaging, teacher talk, teacher talk functions, pre-service teachers, school placement

\section{Introduction: Code-switching and translanguaging}

The topic of the article comes from a strong belief of the author that formerly employed foreign language teaching approaches that have tried to eliminate the use of mother tongue in the foreign language classroom at the same time have not only 
eliminated potential learning sources for pupils but have also deprived them of the safety which reliance on L1 offers. The aim of this article is to support the newly promoted approach of translanguaging as a legitimate teaching/learning strategy in the FL class, allowing for the use of multiple languages (Creese and Blackledge 2010, 2011, 2015).

In his discussion of changing focus in language studies, Coulmas (2018) juxtaposes the earlier static approaches and the present-day dynamic perspective taken by linguists (Table 1).

Table 1: Changing perspectives

\begin{tabular}{|l|l|}
\hline \multicolumn{1}{|c|}{ Static } & \multicolumn{1}{|c|}{ Dynamic } \\
\hline Standard language & Multiple varieties, Patois \\
National language & Pidgin, Creole \\
Mother tongue & Home language \\
Heritage language & Community language \\
Diglossia & Heteroglosssia \\
Monolingual speech & Code-switching/translanguaging \\
Native speaker & Bi-/multilingual speaker, Semi-speaker \\
Uniformity & Diversity \\
\hline
\end{tabular}

Source: Coulmas 59.

This modern approach to language studies, embracing what we know about how languages develop and function (the importance of language varieties studied, departing from one language model, language as social phenomenon), focuses on the fact that globalization has brought about a very pronounced need to allow people to communicate and interact simultaneously in more than in one language. Thus, code-switching and translanguaging seem to be naturally occurring phenomena. This kind of authentic communication is observed in non-instructional settings, in target language communities, between local people and newly arrived immigrants or tourists and students. It is time that it found its way into, and also became a legitimate tool in instructional settings of not only second but also foreign language classrooms (Creese and Blackledge 2010, 2011).

\section{The concepts of code-switching and translanguaging: the same or different?}

The concept of code-switching (or alternative terms used: code mixing, code alteration) has been thoroughly discussed in literature (Scotton-Myers and Jake 2009) and described as the possibility of using different languages at different levels of a communication exchange (discourse) in its intrasentential dimension (within the boundaries of one sentence - alternating individual words or phrases) as well as in 
the intersentential dimension (switching between languages beyond the sentence, across the discourse). The conscious language choices made perform communicative and social functions to establish social relationships, dominance and in- /out group belonging as an identity marker, whereas subconscious switches are seen as evidence of how a bi-/multilingual brain functions, stores and accesses language in a situation of, for example, exhaustion or stress (Gabryś-Barker 2012a). Naturally, the latter assumes a separatist view of languages and a bi/multilingual is seen as the sum of two monolinguals (Cook 1991; Singleton 1999; Gabryś-Barker 2005).

The article does not aim to draw a clear line between code-switching and translanguaging. I believe that these two concepts applied to FL instruction differ mainly in the attitude taken. Traditionally, code-switching was perceived as negative, whereas the (fairly) new term of translanguaging proposes to view this linguistic phenomenon as positive (Gabryś-Barker 2019). This difference derives from the monolingual (past) and multilingual (present) perspective taken on language as a tool of communication and interaction. In the context of a foreign language (FL) class, code-switching (CS) seen as negative led to the elimination of the L1 of the learners (and teachers). As a consequence, all FL classroom communication and instruction were to be carried out in the L2/FL. Such an approach was promoted by the audiolingual method, direct method and initially, by communicative language teaching. Each of these approaches and the methods resulting from them proposed immersion in a foreign language as a way of learning it, though using different strategies and techniques. However, there was a time during the 1970s that saw L1 return to the FL classroom, when unconventional methods of language instruction, such as Community Language Learning were gaining in popularity among those who believed that the humanistic psychology they were derived from was a much more effective and holistic way of approaching language teaching/learning. It was believed that, after all, a language is a tool of communication and interaction, thus the process of its acquisition/learning and use need to embrace the full potential of a person, both cognitive and affective, to be successfully achieved.

What is translanguaging (TR)? The concept has strong connections with codeswitching as a communication strategy and is defined in a FL classroom context as:

a process by which students and teachers engage in complex discursive practices that include all the language practices of students in order to develop new language practices and sustain old ones ... (Garcia and Kano 261)

The use of multiple languages and especially in a multilingual classroom is a legitimate strategy for promoting communication and understanding, even at the expense of incorrectness and alternative use of languages (Creese and Blackledge 2010). As mentioned earlier, the main difference between Cs and TR in instructional settings is that of an attitude in which the former was seen as a manifestation of language deficiency, so operating only on a cognitive level (a negative attitude), whereas the latter performs the function of a bridge to understanding, thus 
it operates also on the affective level (a positive attitude). Thus, these two related phenomena need to be considered as having a different value mostly in the context of a FL classroom (but not so much in an L2 immersion context). Coulmas (2018) assumes that in the FL class the use of CS is/was "undermining the effectiveness of teaching", at the same time translanguaging is seen as "a positive strategy of language learning that exploits the learner's linguistic resources to maximize communicative potential (Coulmas 58). The change of approach and attitude can be ascribed to the development of a widely spread multilingualism which grew with the development of globalization and international contacts. As a result, the educational need for instruction in two or more foreign languages became apparent and had an impact on a fast-growing research in multilingualism.

I believe that code-switching and translanguaging in a FL classroom can be seen as near-synonyms and the only difference in the discussion of these concepts lies in the negative (the former) and the positive (the latter) attitude to each of them, which stems from a different approach to language use in natural multilingual contexts versus the instructional context of a foreign language class, in which learners are native speakers of one language (monolingual classes) and at the same time they are exposed to more than one foreign language in their studies.

\section{Approaches to language choices in a monolingual class}

When discussing — be it code-switching or translanguaging, it is necessary to point out that both related phenomena are very much contextualized. For example, in a British environment of a multinational community and thus, numerous multinational schools and classes, translanguaging or, to adopt a neutral term, alternating languages, is a necessary tool for communication, and even basic functioning between teachers, learners and between learners themselves. Thus, the importance of mixing languages at different levels of communication, learning and generally functioning at a given school are not to be questioned. What is more, appropriate procedures should be implemented for this to happen smoothly. Even if the school runs classes in English as a second language, they should accommodate multiple languages in their daily instructional practices as an all-inclusive strategy. The premise to promote translanguaging is absolutely mandatory for school policies and derives first of all from the social need to accommodate every pupil and thus to create equal opportunity and security at school. One of the best examples of where such policies are implemented is the Basque educational system (Lasagabaster 2001; Cenoz and Gorter 2015; Aldekoa 2018), in which the coexistence of three languages in a FL class is a legitimate way of teaching. One such example is given by Aldekoa (2018), who demonstrates how didactic sequences in a FL class can be taught successfully through implementation of purposeful and well-thought through translanguaging as a communication and didactic tool. 
In the context of a (fairly) monolingual society such as Poland, the belief that the use of multiple languages in a classroom, including the mother tongue - at least for the time being - is also justified, however on different grounds (Sobkowiak 2019). These pupils have a common language, so no problems of communication, socialization and learning are likely. A foreign language is learnt to offer pupils other options in life, career, a better job, friends across the world or travelling in the expectation of being able to find one's way in a foreign country, etc. So, the initial motivation to communicate successfully in a class using other languages than the target language is not there. But what is definitely there is what we understand as the need to feel secure by being able to say something one knows and not to make a fool of oneself, not finding words in a language not yet learnt at the level demanded for this purpose. The mother tongue becomes handy. It also becomes useful in understanding that languages are both different and similar, and in allowing us to implement this knowledge in reflecting on the newly learnt words or sentence structures, etc. This approach to language instruction was long ago implemented in the traditional teaching of languages, which assigned a big role to the mother tongue of a learner (however not always in the right proportion, as is the case of grammar translation instruction) but dropped with the arrival of the belief that language immersion would solve all FL teaching/learning problems. Such a position derived from the fact that L2 learning was compared to L1 acquisition, languages were believed to be compartmentalized in our brain as separate systems and the language classroom was to replicate the authentic context of language immersion in L2/FL, where all the material was to be presented in L2/FL (Cook 2008). Criticizing this approach, Cook $(2001,2005)$ proposes something that actually a lot of teachers do but feel rather guilty about doing, and that is using L1 positively in a language classroom for the purposes of presenting the meaning and checking its understanding on the level of individual words and sentences as well as in explaining grammar or organizing and managing procedures (discipline, assessment, individual feedback). His purpose is to eliminate this sense of guilt.

\section{Teacher talk in a (FL) classroom}

The choice of language in the context of a foreign language classroom is very much determined by the teacher. It is expressed by the teacher's own language use for various purposes during a FL lesson as expressed by teacher talk (discourse), the focus of this discussion.

\subsection{Defining the concept}

FL teacher talk (TT) or teacher discourse can be expressed both verbally and by non-verbal markers of communication. It demonstrates a planned strategy which 
exemplifies a teacher's approach to teaching. It is also expressed by instances of spontaneous and thus authentic communication in a classroom (e.g. in off-task exchanges with students) (Gabryś-Barker 2018). Teachers' choice of language expresses not only the content but also his/her personality, attitude to the subject matter, attitude to learners and often expresses various emotions. In its non-verbal dimension TT takes many different forms. These could be posture, touching behaviour, facial expressions, and eye behaviour (eye contact). Also, teacher distance - proxemics demonstrates a teacher's approach to the personal and social space of a learner and is a form of TT. By different paralinguistic elements which focus on not so much what as how something is being said, i.e. by tone, pitch rhythm, timbre, loudness and inflection, a teacher communicates something with his/her learners (for a thorough discussion of non-verbal TT see Knapp and Hall 1992, 2006; Gregersen 2007).

Conceptualization and research on teacher talk comes predominantly from studies on foreigner talk (FT) (Hatch 1981; Chaudron 1993; Osborne 1999; Fedorova 2015) and it is seen as a modified version of a target language, which brings about understanding on the part of FL learners. In other words, TT is like foreigner talk (FT), where L1 use is seen as what Cook (2008) calls "a guilt-making necessity". The adaptation of language in TT, just like in FT, embraces different dimensions of its performance (Table 2).

Table 2: Language modifications in TT

\begin{tabular}{|l|l|}
\hline $\begin{array}{c}\text { Language } \\
\text { modifications }\end{array}$ & \multicolumn{1}{c|}{ Examples } \\
\hline Phonological & $\begin{array}{l}\text { Exaggerated articulation. Extended pauses. Slower rate of speech. Less } \\
\text { reduction of vowels and consonant clusters. Louder delivery. More standard } \\
\text { "literary" pronunciation }\end{array}$ \\
\hline Lexis & $\begin{array}{l}\text { More basic vocabulary. Fewer colloquial expressions. Fewer indefinite } \\
\text { pronouns. Stylistically neutral }\end{array}$ \\
\hline Syntactic & $\begin{array}{l}\text { Fewer subordinate clauses. Fewer words by clause. Shorter length of } \\
\text { utterances. Higher proportion of simple present tense. Higher proportion of } \\
\text { well-formed sentences }\end{array}$ \\
\hline Discourse & $\begin{array}{l}\text { More first-person reference. Fewer functions per time unit. More teacher- } \\
\text { initiated moves. More conversational frames. More self-repetitions. More } \\
\text { verbalization per function. }\end{array}$ \\
\hline
\end{tabular}

Source: Gabryś-Barker, "Emotionality in L2 teacher discourse" 304.

\subsection{Teacher talk functions}

In general, teacher talk embraces cognitive tasks which are to be performed in the classroom, which relate to the subject itself (presenting new material, practising, etc.). It also has a managerial dimension, when the teacher organizes and runs the lesson (managerial talk) and responds to learners' needs and feelings (coun- 
selling talk). No less important is the teacher's expressive talk, in which a teacher expresses his/her own feelings about a subject, learners or a situation (Watkinson 2006). A more detailed description of TT is presented by Warford and Rose (2011) in their Foreign Language Teacher Talk Survey (Table 3).

Table 3: Foreign Language Teacher Talk Survey

\begin{tabular}{|l|l|l|}
\hline Main aspects/categories of TT & \multicolumn{1}{|c|}{ Specific categories } & \multicolumn{1}{|c|}{ Role } \\
\hline Procedural & $\begin{array}{l}\text { Taking attendance, announcements, } \\
\text { giving directions to an activity, } \\
\text { introducing a topic, goals, giving } \\
\text { agenda for a lesson, etc. }\end{array}$ & Organizer \\
\hline $\begin{array}{l}\text { Instructional (discourse related } \\
\text { to lesson content) }\end{array}$ & $\begin{array}{l}\text { Introducing new language, } \\
\text { reviewing, modelling, drills, } \\
\text { activities and exercises, etc. }\end{array}$ & $\begin{array}{l}\text { Knowledge giver/ } \\
\text { source of input }\end{array}$ \\
\hline $\begin{array}{l}\text { Offering and soliciting feedback } \\
\text { (discourse related to progress, } \\
\text { repair sequences/corrections) }\end{array}$ & $\begin{array}{l}\text { Explicit and implicit corrections, } \\
\text { praising, comprehension check, } \\
\text { giving feedback, etc. }\end{array}$ & $\begin{array}{l}\text { Assessor/corrector/ } \\
\text { evaluator }\end{array}$ \\
\hline $\begin{array}{l}\text { Spontaneous L2/FL talk } \\
\text { (interaction on and off task) }\end{array}$ & $\begin{array}{l}\text { Eliciting student talk, facilitating } \\
\text { communication, expressing } \\
\text { humour/empathy/sympathy, etc. }\end{array}$ & $\begin{array}{l}\text { Facilitator/ } \\
\text { communicator/ } \\
\text { Interlocutor }\end{array}$ \\
\hline $\begin{array}{l}\text { Classroom management/ } \\
\text { maintaining discipline }\end{array}$ & $\begin{array}{l}\text { Reminding the rules of behaviour, } \\
\text { encouraging engagement in tasks, } \\
\text { discouraging misbehaviour, etc. }\end{array}$ & Manager /facilitator \\
\hline
\end{tabular}

Source: based on Warford and Rose 2011 in Gabryś-Barker, "Emotionality in L2 teacher discourse" 303.

\section{Code-switching/translanguaging or simply, alternating languages in a FL class (the study)}

\subsection{Methodology of the study}

The main objective of this pilot study is the observation of how FL teachers use their teacher talk with respect to the language choices they make at different stages of a FL lesson to fulfil its different purposes. It was assumed initially that there would be a difference between experienced EFL teachers and trainee teachers involved in their school placement teaching at the moment of data collection due to much more extensive teaching experience of the former group.

The following questions were formulated:

1. What language choices were made during lessons of English (L1 versus $\mathrm{FL} / \mathrm{Ln})$

2. What were the reasons for CS/translanguaging?

3. How does language behaviour of the in-service and pre-service teachers compare? 
The subjects involved in the study were of two groups of EFL teachers. Group 1 consisted of 36 in-service teachers with at least 5-years' experience of teaching English, who were observed during 180 English lessons by pre-service 2nd year students during their school placement period (a non-participatory observation). Group 2 consisted of 15 pre-service teachers, who observed themselves during 75 English lessons. They were 3rd year university students of English during their school placement semester (participatory observation). Both observation (group 1) and self-observation (group 2) took place in primary schools in the region, so the pupils were young learners and young adolescent learners of English at A1 and A2 levels of advancement in English. Thus, it can be assumed that the contexts of observation and self-observation were homogenous.

As mentioned above, the data was collected by means of an observation, in which parallel schemes, IN-SERVICE TEACHER LANGUAGE BEHAVIOUR DURING A FOREIGN LANGUAGE LESSON (group 1) and SELF-OBSERVATIONS OF PRE-SERVICE TEACHERS' LANGUAGE BEHAVIOUR DURING A FOREIGN LANGUAGE LESSON (group 2), prepared in advance, were employed (Table 4).

Table 4: Observation scheme for non-participatory observation (group 1) and participatory observation (group 2)

GROUP PROFILE (age, language level):

\begin{tabular}{|l|l|l|l|}
\hline Language choice & When ................... & Purpose................... & Comment/examples \\
\hline L1 (Polish) & & & \\
\hline FL (English) & & & \\
\hline
\end{tabular}

The data collected were classified according to pre-determined general deductive categories, i.e. language choice (L1 versus FL, when - the stage of a given lesson, didactic and non-didactic purposes), however no detailed answer options were offered to the participants, as for example in the case of purposes, which were solely generated and defined by the subjects themselves. These were later collated and discussed in the analysis of the data. The trainees were also asked to give examples of their language use in class. The following unedited observation schemes can serve as sample illustrations of the data, where Table 5a presents the self-observations of a trainee teacher (quite simple) and Table $5 \mathrm{~b}$ demonstrates the language behaviour of an experienced teacher observed (more elaborate). 
Table 5a: A sample observation scheme (a trainee teacher self-observation)

\begin{tabular}{|l|l|l|l|}
\hline $\begin{array}{l}\text { Language } \\
\text { choice }\end{array}$ & \multicolumn{1}{|c|}{ When................ } & Purpose................. & Comment/examples \\
\hline $\begin{array}{l}\text { L1 } \\
\text { (Polish) }\end{array}$ & $\begin{array}{l}\text { When learners do not } \\
\text { understand some words/ } \\
\text { comments/statements } \\
\text { Giving comments to exercises } \\
\text { Explaining new words } \\
\text { Explaining new grammar } \\
\text { rules }\end{array}$ & $\begin{array}{l}\text { To ensure } \\
\text { comprehension }\end{array}$ & $\begin{array}{l}\text { Students feel more } \\
\text { secure when I use } \\
\text { Polish. } \\
\text { Students do not feel } \\
\text { confused when I use } \\
\text { Polish }\end{array}$ \\
\hline $\begin{array}{l}\text { FL } \\
\text { (English) }\end{array}$ & $\begin{array}{l}\text { Practice of pronunciation } \\
\text { Singing songs and reading } \\
\text { stories (initial exposure to } \\
\text { language) } \\
\text { Giving feedback }\end{array}$ & $\begin{array}{l}\text { To offer a correct model } \\
\text { To develop fluency } \\
\text { To expose learners to } \\
\text { a foreign language }\end{array}$ & $\begin{array}{l}\text { Thanks to this exposure } \\
\text { to English, the students } \\
\text { are more familiar with } \\
\text { it and find it more } \\
\text { natural to use }\end{array}$ \\
\hline
\end{tabular}

Table 5b: A sample observation scheme (an experienced teacher observed)

\begin{tabular}{|c|c|c|c|}
\hline $\begin{array}{l}\text { Language } \\
\text { choice }\end{array}$ & When. & Purpose.. & Comment/examples \\
\hline $\begin{array}{l}\text { L1 } \\
\text { (Polish) }\end{array}$ & $\begin{array}{l}\text { When the teacher } \\
\text { introduces new } \\
\text { grammatical rules and } \\
\text { vocabulary } \\
\text { Conducting the test } \\
\text { and giving feedback } \\
\text { on the test } \\
\text { Giving grades and } \\
\text { assigning homework } \\
\text { Maintaining discipline }\end{array}$ & $\begin{array}{l}\text { To assure clarity and } \\
\text { understanding } \\
\text { To get children's attention } \\
\text { To calm children down }\end{array}$ & $\begin{array}{l}\text { The teacher explains first in } \\
\text { English and then in Polish } \\
\text { (with examples in English) } \\
\text { All the tasks are explained } \\
\text { in Polish } \\
\text { First in English, then in } \\
\text { Polish } \\
\text { Reprimands given only in } \\
\text { Polish, e.g. Przestan gadać! }\end{array}$ \\
\hline $\begin{array}{l}\text { FL } \\
\text { (English) }\end{array}$ & $\begin{array}{l}\text { Giving instructions } \\
\text { At the beginning of } \\
\text { the lesson, short chats } \\
\text { Apologising and } \\
\text { requests }\end{array}$ & $\begin{array}{l}\text { To accustom children to } \\
\text { foreign language use in } \\
\text { class } \\
\text { To encourage children to } \\
\text { speak English } \\
\text { To catch children's } \\
\text { attention and expose them } \\
\text { to polite phrases in English }\end{array}$ & $\begin{array}{l}\text { Use of Classroom English, } \\
\text { e.g. Open the book, your } \\
\text { turn, next. } \\
\text { Off-task talk, e.g. How are } \\
\text { you today? What is the } \\
\text { weather like today? } \\
\text { Classroom talk, feedback, } \\
\text { e.g. I was wrong, Please } \\
\text { open the window. }\end{array}$ \\
\hline
\end{tabular}




\subsection{Data presentation}

In the presentation of data, the group of experienced teachers and their language behaviour will first be presented and discussed. It will be followed by a more detailed discussion of trainee data, supplemented by the additional comments they made when self-observing. It will be complemented by a comparison of these two groups of teachers.

\subsubsection{Experienced teachers}

In their choices of $\mathbf{L 1}$ use in English classes, the experienced teachers were seen as freely referring to the mother tongue of the learners (Table 6).

Table 6: L1 use by experienced in-service teachers (group 1)

\begin{tabular}{|l|c|}
\hline \multicolumn{1}{|c|}{ Area } & Answers in \% \\
\hline Vocabulary introduction/explanation/translation & 55 \\
\hline New grammatical rules & 55 \\
\hline Dealing with disruptive behaviour & 36 \\
\hline Introduction to the new lesson & 22 \\
\hline Lesson organization & 23 \\
\hline One-to-one communication with learners & 23 \\
\hline Homework assignment and feedback (21\%) & 21 \\
\hline
\end{tabular}

It seems that most of the observed teachers used L1 when in the material presentation stages of a lesson, both with reference to vocabulary and grammar explanation. L1 was the source language (in both cases 55\%). Also, in the context of misbehaviour incidents and to some extent personal communication, Polish was the language of choice, however, to a much lesser extent. The reasons given by the observers predominantly had to do with the need to make comprehensible what was taught on the cognitive level (56\%) and to support learners (23\%) as well as to calm the class down (36\%). Another reason also voiced related to clarity of assessment and thus the choice of Polish to express it. All in all, the mother tongue of the learners performed all the functions of TT as enumerated by Watkinson (2006): cognitive, expressive, counselling and managerial.

As far as the use of English in classes is concerned, the observed teachers seemed to believe that the part of the lesson that focused more on off-task behaviour should be an additional and as such, perhaps less-stressful opportunity to ex- 
pose their learners to English, thus English is most visible in the context of lesson opening and closing talk (Table 7).

Table 7: FL use by experienced in-service teachers (group 1)

\begin{tabular}{|l|c|}
\hline \multicolumn{1}{|c|}{ Aspect } & Answers in \% \\
\hline Lesson opening/closing (off-task) & 85 \\
\hline Giving instructions to the tasks & 36 \\
Practice stage of the lesson (tasks) & 36 \\
\hline Communication activities & 35 \\
\hline Correction/feedback/revision & 32 \\
\hline Vocabulary presentation/explanation & 30 \\
\hline
\end{tabular}

What is interesting here is that teachers' readiness to present material in a foreign language, and especially grammar, is somehow less frequent than in the case of L1 use (30\% vs 55\%). At the same time, the use of English in practice and production stages (especially in communication tasks) is quite prominent (36\% and $35 \%$ ). According to the students making observations, these experienced teachers used English:

- to offer their learners more exposure to a foreign language (25\%);

- to present a model of language, mostly in relation to its pronunciation (25\%);

- to encourage development of speaking skills and thus, develop fluency and communicative abilities of the learners (20\%); $(14 \%)$;

- to enhance learners' motivation and encourage them to use the language

— to make them memorize language better (0.5\%).

In other words, in their choice of using English, trainees focused mostly on cognitive and expressive functions (Watkinson 2006), with emphasis on off-task communication in a FL.

\subsubsection{Trainee teachers}

The dominant instance of L1 use in language material presentation in the case of trainee teachers, as they noted in their self-observations was even more strongly expressed than it was in the case of experienced teachers. It can be assumed that it exhibits their anxiety whether what they teach will be understood. Hence, their choice of Polish is so prominent at the stages of the lesson related to the language material presentation $(80 \%$ and $60 \%$, Table 8$)$. 
Table 8: L1 use by pre-service teachers (group 1)

\begin{tabular}{|l|c|}
\hline \multicolumn{1}{|c|}{ Aspect } & Answers in \% \\
\hline New grammatical rules & 80 \\
\hline Vocabulary introduction/explanation/translation & 60 \\
\hline Cases of lack of comprehension/task difficulty & 26 \\
\hline Lesson organization & 23 \\
\hline One-to-one communication with learners & 23 \\
\hline Homework assignment and feedback & 21 \\
\hline Introduction to the new lesson & 13 \\
\hline Information on school events, correcting. & 1 \\
\hline
\end{tabular}

Again, as was observed in the case of the experienced teachers, the trainees in their comments justify the reasons for using the learners' mother tongue in these terms:

— assuring learners' comprehension (70\%);

- supporting/encouraging learners' performance in English (20\%);

— facilitating learning (20\%);

— offering not only cognitive, but also affective safety (15\%).

In other words, the cognitive, managerial and counselling functions of TT were consciously performed in L1. In the case of FL use in the TT of the trainee teachers, the same functions were performed by the students as in the case of L1, however, instances of English use were different (Table 9).

Table 9: FL use by pre-service teachers (group 1)

\begin{tabular}{|l|c|}
\hline \multicolumn{1}{|c|}{ Aspect } & Answers in \% \\
\hline Practice stage of the lesson (task performance) & 60 \\
\hline Giving instructions for the tasks & 26 \\
\hline Pronunciation practice & 26 \\
\hline Explaining new words & 26 \\
\hline Giving feedback & 26 \\
\hline Other: Offering guidance, off-task communication & 5 \\
\hline
\end{tabular}

Predominantly, it was language practice that yielded trainees' use of English (60\% and 26\%). Surprisingly, very little significance was assigned to the use of English in the case of off-task communication (which was the case with the experienced teachers), which demonstrates that trainees, having virtually no experience of teaching, are not fully aware that the use of a FL in off-task communication not only builds a rapport between teacher and learners, but above all offers 
the latter extra exposure to a FL. The reasons for the use of English given by the trainees focused on:

- offering learners exposure to a foreign language, however mostly in the practice stage of the lesson (60\%);

- presenting a model of language (strong focus on pronunciation, 26\%);

- development of speaking skills/fluency/communication (25\%).

In other words, cognitive, managerial and counselling functions of TT were consciously performed in a FL, but what seemed to be missing was trainees' awareness of the value of off-task communication in a FL (expressive function of TT).

\subsubsection{Focus on trainee teachers: $\mathrm{L} 1$ versus FL use in class}

In additional comments that the trainees provided in their self-observation reflections, two approaches were taken in relation to language choices made in TT. In the first approach, constituting the majority tactic of $80 \%$ of trainees, admitting to making language choices in their TT was presented in the following proportions: L1 use of $60-75 \%$, FL use of $25-40 \%$. The justification for the dominant position of L1 was given as low self-assessment of trainees' own proficiency, their insecurity about making grammatical mistakes and lack of fluent communication on the part of trainee teachers. In their own words:

- I sometimes get nervous and fear tightens my throat ...

- I struggle with talking in English with my students ...

- I am still a little bit insecure when it comes to speaking fluently in English in class ...

The remaining $20 \%$ of the trainees represent those students who used L1 less, i.e. $30-40 \%$ but who chose a FL in $60-70 \%$ of instances. They considered their teaching as an additional opportunity to develop their language skills and their own confidence in using English:

- I talk in English a lot of time. What I observed is that before I started the job, I had been less fluent ...

- This job helped me to be more secure in communication and to control my language ...

It can be assumed that apart from their knowledge of teaching methods, the choices that trainee teachers make in their classroom performance are very much determined by the way they see themselves as FL learners/users. Their own perceived language ability influences language choices made by them. Perhaps this is an important indication that teacher training programmes should also develop future teachers' ability to reflect upon themselves and develop objective ways of assessing themselves not only in relation to teaching itself but also to their language competence and performance levels, as it were, to reflect on their strong and weak language points. 


\section{Observations and comparisons}

The data collected in non-participatory and participatory classroom observations shows that both experienced and trainee teachers alternate between languages at similar stages of the lesson and for similar purposes. The choice of a language to be used is conscious and well-justified. At the same time, it cannot be denied that there are also some differences between these two groups of teachers (Table 10).

Table 10: In-service versus pre-service teachers' dominant language choices

\begin{tabular}{|l|l|l|l|}
\hline \multicolumn{1}{|c|}{ Group } & \multicolumn{1}{c|}{ L1 use } & \multicolumn{1}{c|}{ FL use } & Functions \\
\hline $\begin{array}{l}\text { In-service teachers } \\
\text { (group 1) }\end{array}$ & disruptive behaviour & off-task- communication & affective \\
\hline $\begin{array}{l}\text { Pre-service } \\
\text { teachers (group 2) }\end{array}$ & $\begin{array}{l}\text { introduction to the new lesson- } \\
\text { presentation of material }\end{array}$ & $\begin{array}{l}\text { extensive pronunciation } \\
\text { practice }\end{array}$ & cognitive \\
\hline
\end{tabular}

The most visible difference occurs in the experienced teachers' attention paid to affect in their classroom but dealing with classroom-related negative incidents such as misbehaviour in the L1, as the mother tongue is often perceived as an affectively stronger language (Gabryś-Barker 2005, 2019a; Dewaele 2013). At the same time, in the instances of developing a rapport with the learners (off-task communication), FL is seen as more effective, as it allows the teachers to keep a certain distance and hold a privileged position, being more confident in their language use than their learners are. The trainee teachers almost totally ignored the affectivity side of their language choices and decided that L1 use is more appropriate in the presentation stage of the lesson, whereas FL use was more appropriate as the source for a correct model of the language with a very clearly expressed emphasis on pronunciation.

All in all, as in the case of the origins of general teacher/trainee beliefs about teaching, also in the specific context of code switching/translanguaging/alternating languages, the language choices made resulted not only from experience (experienced teachers), but also from individual attitudes, perceptions and personal preferences grounded in theory and one's learning history, in other words, transfer of training. The choices of language were clearly determined by the stages and didactic sequences of the lesson and demonstrated not only compartmentalization of these sequences/stages of a FL lesson but also compartmentalization of languages ( $\mathrm{L} 1$ versus FL). It is true of both experienced and trainee teachers in this study that they all act consciously in making their language choices and alternating between languages, which is clearly determined by

- their learners' age and resulting from this, degree of language/metalinguistic awareness and cognitive potential; 
- their learners' language level determining the effective degree of exposure to a FL, appropriate degree of language sophistication, comprehension level;

- in the case of trainee teachers, their perceived language competence is seen by them as developing through an extensive use of a FL in class, at the same time their perception of the inadequacy of their language competence makes them refrain from its use, indicating fear of mistakes, lexical deficiency, fear of losing face as a language expert. This is also seen in avoidance of a FL in a less-controlled context of off-task communication (trainees' comments).

Whenever we label the phenomenon of alternating between languages, codeswitching or translanguaging, it seems to operate as a successful pedagogic strategy and tool in FL instruction. Summarizing the teacher and trainee behaviours, it can be observed that a conscious decision on language choice (L1 vs FL) is quite clear cut. L1 is used on a cognitive level for didactic purposes: comprehensibility, time economy and on an affective level to facilitate learning and give learners cognitive and affective security. However, more often than not, guilt about L1 use in the FL class creeps in. Cook (Second Language Learning 418) suggests that it can be eliminated by developing teachers' perceptions that using L1 in class is a legitimate tool used

— to provide a short-cut for giving instructions and explanations where the cost of the L2 is too great;

- to build up interlinked L1 and L2 knowledge in the students' minds;

- to carry out learning tasks through collaborative dialogue with fellow students;

- to develop L2 activities such as code-switching for later real-life use.

It was interesting to see that the trainee teachers, as novices often do (GabryśBarker 2012, 2016), focused very much on their own classroom performance, exhibiting the need to be well-perceived by their learners. Such an attitude made them more conscious of their own language abilities and often (as mentioned earlier in this text) this fact made them refrain from using a FL on the one hand. On the other hand, bearing in mind the ideas promoted by communicative language teaching they were acquainted as students of TEFL methodology, they understood language immersion as a facilitative aspect of FL learning for their students.

\section{Final remarks: on improving training programmes for FLT}

The aims of this paper and the small-scale comparative study carried out were to determine to what an extent EFL teachers and teacher trainees are aware of which languages they choose to use and why they choose to use them in their EFL classrooms. Though the subjects were both experienced teachers and those who are not 
yet fully qualified, the focus is very much on the latter group. It was the trainees who were the sole data collectors in the study. However, most importantly, the ultimate goal of the study was to make future teachers reflect on a very important aspect of their classroom behaviour, that is, teacher talk. The observations derived from the corpus of observations can serve as an indication of which areas of teacher training require additions or modifications of content. In view of recent literature on the topic and the actual beliefs trainees hold, the need to change their frames of mind as far as language choices used in a FL classroom are concerned seems urgent. First of all, guilt at using the mother tongue needs to be addressed by pointing out the advantages of its use at different stages of a FL lesson, naturally bearing in mind appropriate proportions between L1, FL/Ln use, so as not to turn a FL lesson into L1-based instruction. However, the good old need for contrastive analysis of languages (L1 vs FL) and translation techniques as exemplifications for how different languages work on the level of lexis and syntax can be legitimately implemented as comparative activities. Native speakers' competence in L1 can add to the generation of ideas and cross-curricular knowledge learners possess but feel inhibited to express due to a limited FL repertoire.

There is a lot of insecurity about using a FL on the part of learners; the insecurity of teachers (and not only trainee teachers) as to their own language competence is less obvious and less frequently commented on. Thus, teacher training programmes should not neglect this side of the syllabus, both on the level of students' awareness of their own abilities but also introducing them to various strategies for dealing with their own language anxieties. Promoting the view that learners' exposure to a FL in class is a good thing, there should be for example more attention paid to what trainees do in their off-task communication and propose ways of introducing it together with so-called classroom language (e.g. as classroom English) used for off-task but also referring to language of giving instructions or managing the lesson by the teacher.

As part of developing the effective but also satisfactory teaching experiences of newly qualified teachers of FLs, the model of reflective practice should be implemented (Gabryś-Barker 2012; Gregson and Hillier 2015). In relation to the topic discussed in this paper, this reflectivity process would include the need to develop trainees' awareness of their language presence in class and make them reflect upon it and thereby give them more security in their first classroom experiences as EFL teachers.

\section{References}

Aldekoa, A. 2018. "Gure Ikastola en tres languages: the teaching and learning of trilingual oral expository skills by means of a didactic sequence." Theory and Practice of Second Language Acquisition 4(2). 73-92. 
Cenoz, J. and D. Gorter. 2015. (eds.). Multilingual Education. Between Language Learning and Translanguaging. Cambridge: Cambridge UP.

Chaudron, C. 1993. Second language Classrooms: research on Teaching and Learning. Cambridge: Cambridge UP.

Cook, V. 1991. “The-poverty-of-the stimulus argument and multicompetence.” Second Language Research 7(2). 103-117.

-. 2001. Second Language Learning and Language Teaching. 4th ed. London: Hodder \& Stoughton.

—. 2005. "Basing Teaching on the L2 User." In: Llurda, E. (ed.). Non-Native Language Teachers: Perceptions, Challenges and Contributions to the Professions. New York, NY: Springer, 47-61.

Coulmas, F. 2018. An Introduction to Multilingualism. Language in a Changing World. Oxford: Oxford UP.

Creese, A. and A. Blackledge. 2010. "Translanguaging in the bilingual classroom: A pedagogy for learning and teaching?" Modern Language Journal 94(1). 103-15.

—. 2011. "Separate and flexible bilingualism in complementary schools: Multiple language practices in interrelationship." Journal of Pragmatics 43. 1196-1208.

—. 2015. "Translanguaging and identity in educational settings." Annual Review of Applied Linguistics 35. 20-35. doi:10.1017/S0267190514000233.

Dewaele, J. M. 2013. "Multilingualism and Emotions." In: Encyclopedia of Applied Linguistics. Retrieved from Research gate. 4 Nov. 2019.

Fedorova, K. 2015. "Foreigner talk. A register or registers?” In: Agha, A. (ed.). Registers of Communication. Helsinki: Finnish Literature Society. Studia Fennica Linguistica, 138-49.

Gabryś-Barker, D. 2005. Aspects of Multilingual storage, processing and retrieval. Katowice: U of Silesia P.

- 2012. Reflectivity in Pre-Service Teacher Development. A Survey of Theory and Practice. Katowice: U of Silesia P.

—. 2012a. "Language, code-switching and attrition.” In: Gabryś-Barker, D. (ed.). Readings in Second Language Acquisition. Katowice: U of Silesia P, 161-74.

- 2016. "Caring and Sharing in the Foreign Language Class: On a Positive Classroom Climate." In: Gabryś-Barker, D. and D. Gałajda (eds.). Positive Psychology Perspectives on Second Language Teaching and Learning. Heidelberg-Berlin: Springer, 155-74.

-. 2018. "Emotionality in L2 teacher discourse: Implications for teacher education and future research direction." In: Dios Martinez Agudo, J. de (ed.). Emotions in Second Language Teaching: Theory, Research and Teacher Education. Cham: Springer, 301-21.

—. 2019. "Applied Linguistics and Multilingualism." In: Singleton, D. and L. Aronin (eds.). Twelve lectures in Multilingualism. Bristol: Multilingual Matters, 35-64.

García, O. and N. Kano. 2014. "Translanguaging as process and pedagogy: Developing the English writing of Japanese students in the US.” In: Conteh, J. and G. Meier (eds.). The Multilingual Turn in Languages Education: Opportunities and Challenges. Bristol: Multilingual Matters, 258-77.

Gregersen, T. 2007. "Language learning beyond words. Incorporating body language into classroom activities." Reflections on English Language Teaching 6(1). 51-64.

Gregson, M. and Y. Hillier. 2015. Reflective Teaching in Further, Adult and Vocational Education. London: Bloomsbury.

Hatch, E. 1981. Discourse and Language Education. Cambridge: Cambridge UP.

Knapp, M. and J. Hall. 1992. Nonverbal Communication in Human Interaction. Philadelphia: Holt, Rinehart and Winston, Inc.

-. 2006. Nonverbal communication in interpersonal relationships. Boston: Allyn and Bacon.

Lasagabaster, D. 2001. "Bilingualism, immersion programmes and language learning in the Basque country." Journal of Multilingual and Multicultural Development 22(5). 401-25.

Osborne, D. 1999. "Teacher-talk. A sociolinguistic variable. Forum.” Retrieved from dosfan.lib. uic.edu. 20 Apr. 2017. 
Sobkowiak, P. 2019. "Translanguaging in the EFL classroom - the Polish context". A paper delivered at the 31st International Conference on Foreign/Second Language Acquisition, Szczyrk, 16 May 2019.

Scotton-Myers, C. and J. Jake. 2009. "A universal model of code-switching and bilingual language processing and production.” In: Bullock, B. E. and A. J. Toribio (eds.). Cambridge handbook in linguistics. The Cambridge handbook of linguistic code-switching. New York: Cambridge UP, 336-357.

Singleton, D. 1999. Exploring the Second Language Mental Lexicon. Cambridge: Cambridge UP.

Tsui, A. 2008. "Classroom discourse." HKW Scholars Hub. Retrieved from https://hub.hku.ht/bitstream. 29 Apr. 2017.

Warford, R. 2011. "Foreign Language Teacher Talk Survey." Retrieved from web.cortland.edu. 20 Apr. 2017.

Watkinson, A. 2006. Learning and Teaching. Gosport, Hants: David Fulton Publishers. 